\title{
Formation of an Effective Mechanism of Financial and Credit Support Reproduction Process
}

\author{
Tatyana Miroshnikova \\ Vladivostok State University of Economics and Service; Email: tanmir12@mail.ru
}

\section{Doi:10.5901/mjss.2015.v6n5s3p84}

\begin{abstract}
The paper proposes an approach to the assessment of the economic efficiency of financial and credit support reproduction a company's fixed assets for sea transport sectors of the regional economy of the Russian Federation on the basis of an economic-mathematical models describing the process of cash flow development and including sensitivity analysis. The article examines the process of forming an effective mechanism of financial and credit support when reproducing fixed assets of the economic entity; offers forfeiting as the finance vehicle element; introduces comparative analysis of loan financing, leasing and forfeiting and proves the economic viability of the last described. The results of the study to determine the most effective methods of financial and credit support of the reproduction process in the economy may be based on the need to develop a financial mechanism for the Russian financial system in order to ensure sustainable economic development.
\end{abstract}

Keywords: finance methods, financial relations, finance and credit support, leasing (finance lease), forfeiting, loan, fixed assets reproduction.

\section{Introduction}

The investigation and development of methodology of forming an effective financial and credit support when reproducing a company's fixed assets is particularly pertinent in view of today's economic climate in Russia. Financial vehicle is a system of financial relations management with the use of capital gearing and finance methods (B.A. Raizberg and L.S. Lozovsky, 2004). It consists of various elements complying with financial relations. It is the multiplicity of financial interlinkages that prejudges the implementation of many types, forms and methods of organization of financial vehicle elements. The need for developing the elements of financial vehicle with a focus on forfeiting is a priority topic (T.K. Miroshnikova, 2009).

The need for enhancing the scope of implementation of technical reconstruction as one of the main types of fixed assets reproduction has caused changes in the structure of sources of funds. That gives place to modern, unconventional methods of financial and credit support of reproduction process.

The recent increase in investment activities aiming technical modernization and reproduction of fixed assets in the economy is plagued by underdeveloped financial markets, basic concepts of stimulation of investment activity and consideration of the specific characteristics of the investment potential realization (A.D. Sheremet, 2004).

The introduction of the term «forfeiting» as a financial instrument advances the theoretical and methodological basis for further development of the financial vehicle. It is appropriate to examine the relevance of this instrument justifying the economic efficiency and compare it with other funding models (T.K. Miroshnikova, 2013).

\section{The Purpose of Research and Methodology}

The purpose of this study is to evaluate the economic impact of different financing methods for the reproduction of the Russian economy. Further theoretical and practical developments in the field of financing the reproduction process is demanded for the development of regional economy. The calculation is based on the principle of comparing the effect of alternative methods of fixed assets financing.

Economic-mathematical models consist of mathematical expressions that describe the process of formation of streams of payments and relationships, which allow calculating the desired performance characteristics. The main advantage of using the model, as is known, is the ability to simultaneously integrate all the necessary requirements, conditions and proposals. The important factor is some option in the review these facilities during the work with the model, the consistency of all the calculated parameters, finally, the possibility of obtaining behaviors of the studied 
phenomenon (in our case, the method of financing) for various combinations of monetary market, inflation, demand. A feature of the model developed for investment in production, is that it is the basic block in which costs and return on investment (flow of charges) are calculated for each time interval with a specific distribution within it. In the analytical model block defines the required performance indicators. The model allows sensitivity analysis, i.e. the identification of the most important model input parameters and receiving system of evaluation of investment efficiency for a wide range of values of such parameters. We obtain not only point estimates, but also a detailed picture in the form of tables and graphs efficiency values for a variety of possible and expected situations. Evaluation of the effect of the forecast period is made in accordance with the methodology for determining net present value (NPV) based on the discount rate.

Key assumptions and limitations taken into account are as follows: the economic impact is calculated using those industries in which there has been a practical use and application of these coatings. In accordance with the method used to determine net present value (NPV) of economic benefit, the results were given to the current value based on the discount rate by the formula [6]:

$N P V=\Sigma D_{i} /(1+K)^{i}$,

where: NPV- present value; $\mathrm{Di}$ - the amount of economic benefit obtained in the i-th period of the discrete projection period; $\mathrm{K}$ - the discount rate; $\mathrm{i}$ - period.

\subsection{Basic data for calculation}

To justify the efficiency calculations it is necessary to carry out the planning of revenue and costs. These indices are calculated on the assumption of a fully loaded vessel during the year. Revenue was calculated based on the average of tariffs for transportation of cargoes by sea transport on the territory of Kamchatskiy Krai (data were taken from the website of the company the «Trance-the leader of the DV») and the average number of use of the vessel per year. The ship takes on Board four 20 foot containers or four trucks of 20 tons. The cost of freight per ton is $20-25$ rubles per $\mathrm{kg}$, when fully loaded the vessel can work 2-3 days a week. Thus in the first year the amount of revenue was 27540000. The rate of revenue growth was $5 \%$ (the average growth of prices for this service).

To calculate the costs that the company will incur during the operating activities were calculated following elements: fuel costs; the salary Fund; depreciation; insurance of the vessel; the costs of preventive repairs and maintenance of vessels. In this article cost includes the painting of the vessel, the partial replacement of equipment, etc. This cost in the first year is 150 thousand rubles. Based on the data of the ship, it uses diesel fuel; average consumption for the vessel under such conditions is 500 litres per day (provided that the ship is working 18-20 hours a day). According to the characteristics, the ship has 2 diesel generators. On average the ship uses 1 ton per day. The cost of 1 liter of diesel fuel is 33 rubles. Total fuel costs for a year will be 3432000 rubles. The growth rate of the cost of fuel is $5 \%$ per year. For calculation of insurance the standard package of the company «Ingosstrakh» - $8 \%$ of the value of the vessel was taken. It includes the insurance of risks associated with the wreck of a vessel due to natural disasters. Justification of the investment amount is 1150000 dollars or 39100000 rubles that corresponds to the cost of the vessel. For the considered schemes discount rate was 14.9\% (Investment asset renewal (7\%), inflation risk (4\%), industry risk (1,9\%), dependence on external sources of funding (2\%)).

For finding the net present value and other indicators it is necessary to calculate the discount rate. In the process of discounting is usually done the conversion of future costs and outcomes to date. The discount factor is calculated by the formula of compound interest:

$$
\alpha=\frac{1}{(1+r)^{t}}
$$

where $\alpha$ is the discount factor;

$r$ - discount rate;

$\mathrm{t}$ - time (year).

\subsection{Stages of the research}

The logic of the research involves the implementation of the following basic steps.

\subsubsection{First step. The Forfaiting Contract.}

The forfaiting contract is regulated by the law Art. 1, para. 1 L. 1905/1990. The contract of forfaiting was first used by 
Swiss banks during the Second World War. Its special feature is that the banks or the special factoring corporations make advance payment to the supplier of claims which are usually of the type of negotiable instruments (e.g. bills of exchange, checks to order) and embody export claims without recourse for payment against the exporter, in case the claim is not satisfied by the importer. For the security of the agent (forfaiter) the claims for which he makes advance payment are guaranteed by a bank which is credit worthy (Georgiadis, 2000; Psychomanis, 1996).

Forfeiting is a specific form of medium-term foreign trade lending. It is a sale transaction on credit terms, which represents the operation of purchasing loan-subscriber's debentures on non-recourse basis. Non-recourse basis stands for the risks and responsibilities that a fund receiver takes on. Usually documents of indebtedness consist of ordinary bills and bills of exchange.

That type of financing is used by discounting a series of consecutive ordinary bills that serve as the buy-side payment obligations in exchange for goods or services under a contract with the exporter.

Compared to traditional bill discounting, forfeiting:

- Is usually used when supplying equipment of high value

- Is used with long-term delay of payment (from 6 to 10 months beyong traditional 90 or 180 days)

- Includes guarantees or aval of the first rate bank that is necessary for rediscounting (K. R. Adamova 2005).

The participants of a traditional forfeiting transaction are merchant (loaner), buy-side and lending bank (the taker of the creditor's debt). Both a loaner and a buy-side can initiate a transaction. A forfaiter there is a bank or any institutional lender that mediates the lender and the promisors. In international trade a supplier's bank acts as a forfaitor, accepting and clearing bills on non-recourse basis. A bill should be drawn either in one of the freely convertible currencies or in one that is popular at the global market. The principle should be negotiated in every case. Sometimes acquirer's guarantor bank can serve as the fourth participant of transactions that ensures the recovery of debt on a bill. It is a great opportunity for a company to acquire fixed assets at lower cost.

In Russia a traditional forfeiting transaction looks as follows: if a Russian importer after making a contract with a foreign party has proved its creditworthiness, he can pay with a bill instead of cash avoiding advance payment. Yet, this bill must be avalized by Russian bank that is of good reputation at the financial global market. Providing clearer, Russian bank becomes a payment guarantor (A.O. Soldatova, 2013).

After getting avalized bill a foreign exporter presents it to foreign bank that endorsed an agreement with Russian bank for discounting. Upon aval receipt foreign bank pays to the exporter a nominal bill amount, net of discounts. On the expiration of the bill foreign bank tables a bill to the Russian bank and receives money. Russian bank submits the bill to the Russian importer who meets the bill.

This scheme describes a loan taken out by a foreign bank to Russian importer mediated through Russian bank. In addition, a loan period concurs with the currency of a bill. As you can see, forfeiting allows not only avoid advance payment, but, with luck, pay for goods after releasing them on the Russian market, which makes it attractive for Russian importers.

One of other advantages is the price factor as the cost of lending resources in foreign banks is much lower than in Russian banks. Moreover, forfeiting assumes the operating risks.

Forfeiting is a flexible instrument of international finances (Dirk Daube, Susann Vollrath, Hans Wilhelm Alfen, 2008). Most transactions are based on export deliveries, which can be inside the country as well. At the moment forfeiting is is not a traditional financial instrument, but it supplements traditional ones, thus requiring further development.

For calculation the following conditions of the Bank of Jiangsu (China) were used:

- $\quad$ five promissory notes with an annual repayment;

- $\quad$ interest accrues on the portion of debt that is covered by the bill;

- interest rate of $8.5 \%$.

In the calculations the terms of this Bank will be used.

For the first option envisaged that the repayment of principal shall be made in equal amounts, respectively, in each promissory note the amount of $\mathrm{R} / \mathrm{n}$ is recorded. The interest for the loan form number:

$$
P_{i}, P_{i}\left(1-\frac{1}{n}\right), \ldots, P_{i}\left(1-\frac{i-1}{n}\right), \ldots, \frac{P}{n} i \quad t=1,2, \ldots, n
$$

where $P$ is the price of the goods;

$\mathrm{i}$ - rate of simple interest for the period;

$n-$ the number of bills.

The amount of the promissory notes, redeemable at time t, will be

$$
V_{i}=\frac{P}{n}+P i\left(1-\frac{i-1}{n}\right)=\frac{P}{n}[1+(n-i+1) i]
$$


The total amount of accrued interest equal

$$
P i \sum_{i}^{n}\left(1-\frac{i-1}{n}\right)=\frac{n+1}{2} P i
$$

The amount of bill portfolio will be

$$
\sum V_{t}=P\left(1+\frac{n+1}{2} i\right)
$$

From these calculations we can draw the following conclusions:

The annual amount for redemption: 7820000 roubles;

The total amount of interest: 9384000 roubles;

The total sum amounted: 48484000 rubles.

Cash flows upon acquisition of a vessel according to the scheme of forfeiting shows that the NPV is positive (27 788780,2 ,). IR (profitability index) was 1.71, which is higher than the unit and reflects a return on invested capital. Internal rate of return was $21,78 \%$. Since IRR is more than $16.9 \%$, the project provides a positive value of NPV.

Investment profile of the project using forfeiting financing scheme shows that the payback period is about 3 years.

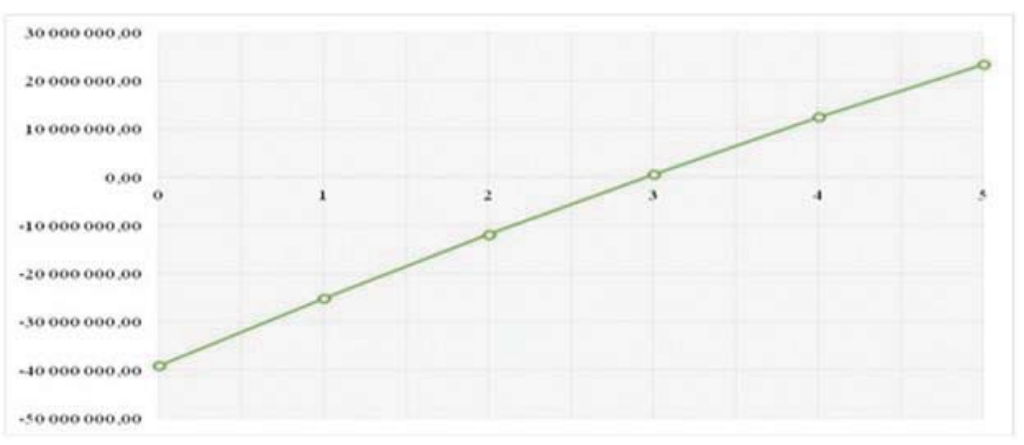

Figure 1 - The financial profile of the project using forfeiting financing scheme

The sensitivity of the cash flows of the lessee with the increase in fuel costs by $10 \%$ and the reduction of revenue by $5 \%$ reflects the reduction in NPV, profitability index and internal rate of return. In this scheme, the funding factor for decrease in profit is also more powerful than the increase in the cost of fuel.

\subsubsection{Second step. The Loan Contract}

Loan is one of the most popular ways of getting money for a certain period of time. Most Russian companies prefer it as a source of funding. Leasing and forfeiting are more complicated, but at the same time have greater advantages.

As a subject of research, loan consists of elements that are closely related. These elements are entities, i.e. loan supplier and loan debtor. Loan supplier grants money. In fact, any entity can become a loan supplier if it lends money.

When a company purchases properties worth more than $\$ 1 \mathrm{mln}$, bank can require larger collateral and guarantees. Collateral is demanded by virtue of law or the contract and it can be provided in the form of company's assets, securities and property rights. The exceptions are assets which have been withdrawn from circulation, statement requiring associated with the loan debtor, particularly, claim for health compensation and other rights, assignment of which is statute-banned.

Guarantees are not less important. As for legal entities, guarantees are given by the head of a company, all the founders (entities with participating interest of more than 20\%) or the spouse, if the head is the only founder. In Russia this term is applied by «Rosselhozbank, LTd».

One of a bank loan features is the targeted use. When a company purchases high-value assets, bank lends large sum of money and starts to control the company's activity. For instance, the bank has the right to demand, at any time, balance sheet, finance statement and its definition. The breach of credit terms causes long-term withdrawal of the credit or implementation of default interest.

Substantial lending can be applied, if a company has existed for a certain period of time and got a fixed income. Also attention is given to goodwill of the company, criminal records, relations with debtors and creditors and accounts 
payable.

To estimate creditworthiness of a lender, quantitative and qualitative analyses of the risks are implemented. The aim is to determine the opportunities, amount and conditions of credit granting. The assessment of financial condition of the company covers the latest 3 years and it is based on methods, produced by the Ministries and investment banks. The most popular methods are offered by «Sberbank of RF».

For calculations there were used the credit conditions of the Bank «Intesa». Loans are granted for five years. Loan interest rate is a $12.75 \%$ per annum. Repayment terms provide for repayment of principal and interest monthly over 5 years. For calculations we use the differential method of calculating payments. A criterion of efficiency is considered the net present value of cash flows. Cash flows upon acquisition of a vessel according to the scheme Bank loan shows that the NPV is equal to the value of $25654930 \mathrm{rbl}$;; IR is 1.66; IRR takes the value of $20.2 \%$.

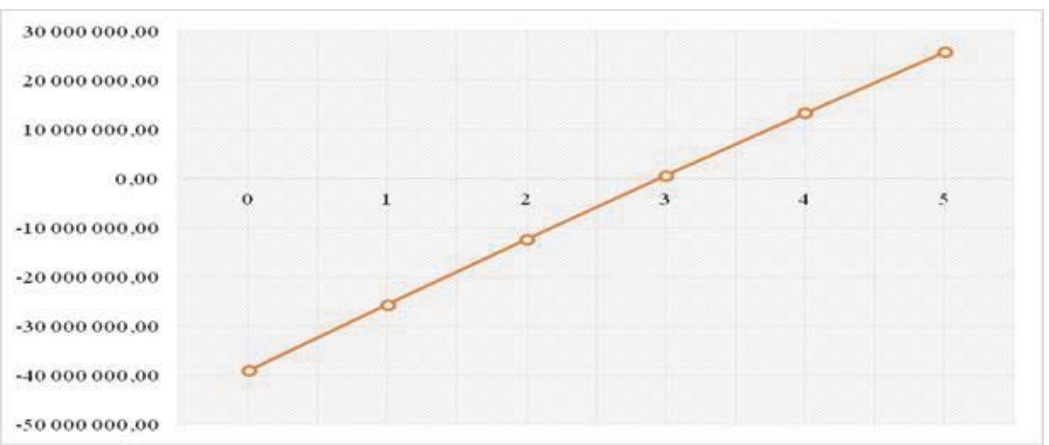

Figure 2 - The financial profile of the project using loan financing

The payback period is about 3 years old that we can see from the figure.

A sensitivity analysis of this project revealed that the most significant factor affecting efficiency is the reduction of revenue by $5 \%$, which can be noted a strong deterioration of performance indicators

\subsubsection{The third step. The Leasing contract.}

Rental of equipment known since the middle ages, for example, the rental of a ship anchors in Venice XI. Leasing is a transaction with the participation of three people (legal and natural entities). In real terms one party buys some assets from another party and then lends it to the third party with a purchase option. The assets of the lessor may be provided in the form of exquipment, transport, construction for production needs and so on. The terms are specified in the agreement of the parties. (Weber, Manfred, 2007)

The main feature of leasing is the absolute power of a user to choose the kind of property and its producer (in accordance with the lessor's abilities). That financial instrument is beneficial to small and medium-sized enterprises, as the procedure of concluding a contract is easier than getting a loan. If the contract conditions are violated, the lessor confiscates property.

The regulatory and legal framework of leasing is based on such regulatory acts as:

Federal Leasing Act No. 164 of 29 October 1998;

Civil Code of RF and the Russian Tax Code;

Federal Act No. 16 of 8 February 1998 «About Russia's joining to UNIDROIT Convention»;

UNIDROIT Convention on International Financial Leasing, Ottawa of 25 March 1988.

Now let us examine the characteristics of leasing, forfeiting and loan as financial instruments and check their viability in terms of purchasing a sea vessel. According to «Expert RA» agency, sea vehicles leasing makes the lowest share of leasing market, though it has increased by $0,5 \%$ for the last two years. Leasing characteristics depend on vessels high value, greater construction and pay-off periods.

According to the effective legal framework, sea vessels are defined as real estate property. That means that ownership rights must be registered, which makes the transaction more complicated. Leased asset can not be pledged until the ownership right is registered by the lessor. Sometimes it can cause ploblems with bank financing.

In practice, vessels leasing goes through a number of stages: choosing the vessel with a certain range of 
functions, choosing either Russian or foreign supplier, negotiating the terms and signing the agreement, supplying the vessel to the lessee (arranging import customs formalities and registration in the name of either lessor or lessee), insuring the item.

When using the scheme of acquisition of a vessel through lease agreement, credit terms of the company «TransFin-M» were used, where loans are granted for four years with annual repayment. Interest rate is $10.5 \%$ per annum.

For the calculation of the lease payments it was proposed to use a formula with coefficient calculation for regular rents. Under such scheme, the lease payment is included in cash flow from financial activity that differs from the calculation of cash flows when determining the lease payments under the scheme recommended by the Ministry of Finance. For accuracy comparisons were calculated in both methods.

At first, lease payment under the scheme recommended by the Ministry of Finance was calculated.

$P L=A O+P C+I N$

where PL is the total amount of lease payments, RUR;

$\mathrm{AO}$ depreciation and amortization or maturity value cost, rbl.

PC - fee loans, RUB.;

IN - reward of the lessor for the provision of property, rbl.

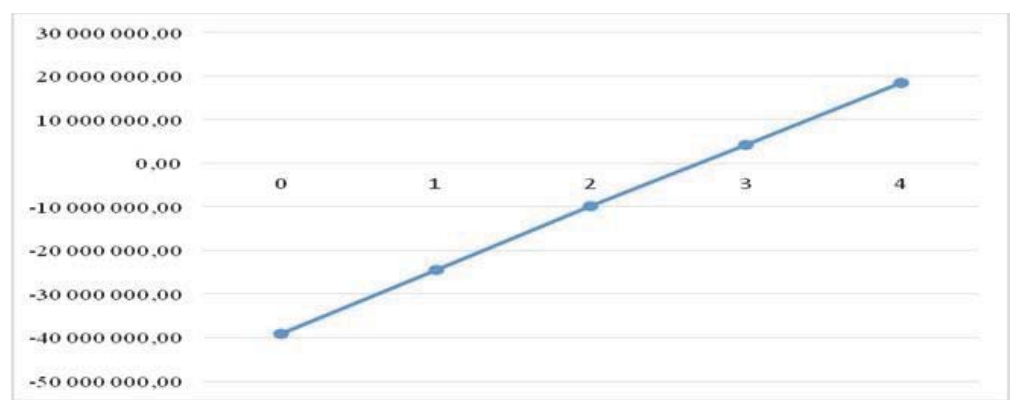

Figure 3 - The financial profile of the project using lease financing

The payback period is 2.6 years; discount rate of 14.9\%; NPV takes the value 18447 075,54 rubles; IR is 1,46; IRR takes the value $18,62 \%$.

These values of efficiency indicators are change in the accrual of lease payments by a factor for regular rents.

To calculate the coefficient for permanent rent the following formula is to be used:

$$
a=\frac{i}{1-(1+i)^{-n}}
$$

a - coefficient ghosts of permanent rent;

$\mathrm{i}$ - interest rate per year;

$\mathrm{n}$ - the lease term in years

The payback period is 2.4 years; discount rate of 14.9\%; NPV takes the value 21818626 rubles; IR is 1,56; IRR takes the value $21,37 \%$.

\section{Comparative Analysis}

The following graph introduces comparative analysis of loan financing, leasing and forfeiting on indicators, such as stransaction object, time limits, finance methods, maximum term, risks and guarantees. The result of investigations is determing the economic viability. 
Table 1 - Comparative analysis of loan financing, leasing and forfeiting

\begin{tabular}{|c|c|c|c|}
\hline Comparison base & Loan financing & Leasing & Forfeiting \\
\hline Transaction object & funds & Equipment or property & ordinary bills and bills of exchange \\
\hline Loan term & Long-term loaning (up to 10 years) & Long-term loaning (up to 10 years) & Long-term loaning (up to 10 years) \\
\hline Amount of loan & Up to $\$ 4,000,000$ & The amount is limited by lessor's abilities & $\begin{array}{l}\text { The amount can be enlarged depending on the } \\
\text { ability of buyers to create syndicates }\end{array}$ \\
\hline Financing method & $\begin{array}{l}\text { Bank lends money and starts to } \\
\text { control the company's activity } \\
\text { (targeted use) }\end{array}$ & $\begin{array}{l}\text { Lessor pays for transaction, lessee makes } \\
\text { lease payments during loan period }\end{array}$ & Forfaiter meets a debt less the discont \\
\hline Risks & $\begin{array}{l}\text { Bank risks to lose own money, but } \\
\text { assumes all the buyer's risks }\end{array}$ & $\begin{array}{l}\text { risksdepending on the agreement terms, } \\
\text { either a lessor or a lessee can bear the risks }\end{array}$ & $\begin{array}{l}\text { Forfaiter can resell the assets on the } \\
\text { secondary market }\end{array}$ \\
\hline Resale & $\begin{array}{l}\text { One bank can resell the loan to } \\
\text { another bank }\end{array}$ & $\begin{array}{l}\text { Rented equipment can be transferred to } \\
\text { another lessee }\end{array}$ & $\begin{array}{l}\text { Forfaiting assets can be resold on the } \\
\text { secondary market }\end{array}$ \\
\hline Guarantees & Guarantee is required & Guarantee from a third party is required & $\begin{array}{l}\text { Guarantee or aval is required from a third party } \\
\text { Possible transfer of finance bill which aim is to }\end{array}$ \\
\hline Pledge type & The assets themselves & Credit by rented assets & $\begin{array}{l}\text { accumulate value for other allowed goals } \\
\text { achievement }\end{array}$ \\
\hline
\end{tabular}

All the financial vehicles are unique and required by the economies of different countries. Economic viability of each of them depends on the goals of the promisee, but all of them are appropriate for large companies that have the overall aim of accumulating funds for different-term projects implementation.

The difference of the financial instruments is based on several indicators:

- Transaction object.

- Loan term.

Not all the banks are ready to provide high-value loans

- Amount of loan.

For instance, commercial banks give credits with a maximum term of $\$ 4,000,000$. The ammount of leasing depends on the company's size and turnover. As for forfeiting instrument, the amount is also limited as buyers can create syndicates. The process of unification is based on the mutual deal of the forfeiters on the share acquired.

- Risks.

Commercial banks do not assume risks connected with purchasing while forfeiter bears a risk of debt non-payment (including policy risk and exchange risk). (Nechaev Andrei, Morozova Aleksandra, 2012)

- Guarantee.

Bank loan demands additional guarantee in the form of stocks. Sometimes leasing does not demand guarantee, but it depends.

If using forfeiting model, aval or guarantee of a bill or note is required. Besides payer, everybody can act as a guarantor of a bill, whose guarantee is valid nevermind, the reasons. In such case aval is equal to guarantee, which is complementary in relation to the primary obligation.

Also it is important to mention, that leasing companies specializing in leasing certain kinds of equipment and thus having long-term relations with suppliers, sometimes can purchase necessary equipment for lower price (or get sale for lot-size orders). That causes the dicrease of the deal price.

On the basis of the above, we can see that leasing and forfeiting funding models are more beneficial, as they include favourable terms, like risks allocation, finance methods and terms.

Let us examine the ways of ship financing in terms of bank loan, leasing and forfeiting.

\section{The Efficiency of Different Funding Schemes}

The efficiency of practical implementation of the investigated financing tool was implemented for transport vessel in fishing industry. We calculated the amount of necessary financial and credit support of the fleet reproduction in fish industry of the Far -East region with the use of forfeiting, leasing and loan. To select efficient financing schemes the criteria of efficiency of investment projects (net present value, profitability index of discounted investment, internal rate of return, payback period) were considered and final amount of the purchase was calculated (E.M. Chetyrkin, 2008).

Calculations were performed for the transport vessel valued $\$ 1150000$ for the period of 5 years with the use of various financing methods. Also sensitivity analysis was performed to identify the impact of two factors - the reduction of revenues and the increase of fuel cost (T.K. Miroshnikova, 2014) 
Table 2 - Efficient criteria for the different funding schemes

\begin{tabular}{|c|c|c|c|}
\hline $\begin{array}{l}\text { Indicators } \\
\text { Vessel cost, rubles } \\
\text { Basic version }\end{array}$ & Credit & $\begin{array}{r}\text { Leasing } \\
1150000 \$\end{array}$ & Forfeiting \\
\hline The final vessel cost (with interest) & 1524142,46 & 1466903 & 1426000 \\
\hline The period of providing & 5 & 4 & 5 \\
\hline The ratio of the final cost to the cost of the vessel & $132,5 \%$ & $127,9 \%$ & $124,3 \%$ \\
\hline$N P V_{0}$ & 754556,76 & 641724,29 & 817317,06 \\
\hline IRR & $20,2 \%$ & $21,37 \%$ & $21,71 \%$ \\
\hline IR & 1,66 & 1,56 & 1,7 \\
\hline Payback period & 3,1 & 2,4 & 3 \\
\hline \multicolumn{4}{|l|}{ With the increase of fuel prices of $10 \%$} \\
\hline$N P V_{1}$ & 723734,64 & 616163,15 & 786494,91 \\
\hline The ratio of the growth rate of $\mathrm{NPV}_{0} \mathrm{~K} N P \mathrm{~V}_{1}$ ) & $104,5 \%$ & $104 \%$ & $103,9 \%$ \\
\hline IRR & $19,1 \%$ & $20,57 \%$ & $19,8 \%$ \\
\hline IR & 1,63 & 1,54 & 1,68 \\
\hline Payback period & 3,2 & 2,4 & 3 \\
\hline \multicolumn{4}{|l|}{ With the reduction of proceeds by $5 \%$} \\
\hline $\mathrm{NPV}_{2}$ & 614456,1 & 525537,27 & 677216,38 \\
\hline The ratio of the growth rate of $\mathrm{NPV}_{0} \mathrm{~K} N P V_{2}$ ) & $122 \%$ & $122,6 \%$ & $120 \%$ \\
\hline IRR & $16,42 \%$ & $17,71 \%$ & $18,27 \%$ \\
\hline IR & 1,53 & 1,46 & 1,59 \\
\hline Payback period & 3,5 & 2,7 & 3 \\
\hline
\end{tabular}

The net present value of each of the funding scheme is positive which indicates their effectiveness. However, not all criteria confirm the effectiveness of the financing schemes.

It is important to notice that the final cost of a loan is the biggest and it exceeds the initial $32.5 \%$, while in the forfeiting scheme cost is the smallest, exceeding the initial $24.3 \%$. This indicator, together with IRR and profitability index, shows that it is the most effective financial instrument.

Special attention should be paid to the leasing scheme, as this scheme has the lowest NPV. Still, the term of granting credit resources is 4 years, unlike 5 as in other two schemes. At the same time the payback period is 2.4 years instead of 3 years.

The sensitivity analysis was held with changing two main factors: revenue decline and rising fuel prices. The change of fuel prices has contributed insignificantly for all three funding schemes. The revenue decline was the most important factor in these calculations. In forfeiting scheme the net present value (NPV) reached $20 \%$ and the payback period has not changed.

\section{Conclusion}

After consideration of the selected finance methods, conclusions were drawn on the most effective scheme. Forfeiting is the most effective scheme of the fleet financing as the final price is the smallest as well as payback period. Forfeiting operations have not yet become traditional, and the potential market is quite large. Under these conditions further theoretical development of forfeiting is required.

We covered the following research areas:

- giving the notion of the financial vehicle by introducing forfeiting as a financial instrument;

- specification of bank loaning, leasing accept and forfeiting when purchasing a vehicle;

- a comparative graph was made to compare 3 financial instruments;

- conclusion was made taking into account the effectiveness of every instrument and its features.

Fixed assets provide an ongoing stream of net operating income, along with a residual value. Fixed capital is often held directly rather than through a financial derivative, and it has other economic characteristics that in the minds of many make it a class of asset that is distinct from other capital assets. For instance, the cost of fixed assets is typically high, compared to operating cost, and the cost tends to be fixed rather than variable. The cost of construction across many types and locations of real estate also tends to be correlated. The value of fixed capital will influence the operating leverage. Capital assets can be valued at their net present value, which discounts an expected stream of value (Eugene F. Brigham, Louis C. Gapenski, 1999). Results of the assessment of the economic efficiency of financing fixed assets for 
the economy of the Russian Federation was based on methodology for determining the present value (NPV) and estimating the economic benefit results based on the discount rate. Development of a financial mechanism is the main issue of providing the reproduction process in the Russian economy. The results of the study to determine the most effective methods of financial and credit support of the reproduction process in the economy may be based on the need to develop a financial mechanism for the Russian financial system in order to ensure sustainable economic development.

\section{References}

Adamova K. R. (2005). Forfeiting from «A» to «Ya». Finance and credit, 24 (138), 109.

Chetyrkin E.M. (2008). Financial mathematics. Moscow, M: «Delo ANCH».

Dirk Daube, Susann Vollrath, Hans Wilhelm Alfen (2008). A comparison of Project Finance and the Forfeiting

Model as financing forms for PPP projects in Germany. International Journal of Project Management, 26 (4), 376-387. http://dx.doi.org/ 10.1016/j.jproman.2007.07.001

Eugene F. Brigham, Louis C. Gapenski, Michael C. Ehrhardt. (1999). Financial Management (9nd ed). Dryden Press.

Grabovoy P.G., Yaskova N.Y.(2004). Finance and credit in the real estate. Moscow, M: «SPC Alpheus».

Georgiadis, Ap. (2000). New Types of Contracts in Contemporary Economy. (p.115). (4nd ed). Sakkoulas (in greek).

John Velentzas et al. (2013). Procedia Economics and Finance 5(757 - 762). 2212-5671.

http://dx.doi.org/ 10.1016/S2212-5671(13) 00088-9.

Miroshnikova T.K. (2014). Capital assets investment opportunities on Russian Far East. International multidisciplinary scientific conferences on social sciences and arts. SGEM. Bulgaria.( vol. 2. pp. 107-115), 2367-5659. DOI: 10.5593/sgemsocial2014B22.

Miroshnikova T.K. (2009). Methods of financial and credit support the modernization of the vehicle fleet of road transport enterprises. Power and control in Eastern Russia, 4 (49), (34-39), 1818-4049.

Nechaev Andrei, Morozova Aleksandra (2012). The system of comparison and correlation of risk types under the forfeiting form of financing with alternative ones under the export of current assets. Journal of National Research Irkutsk State Technical University, (61). (pp.124-128), 1814-3520. http://journals.istu.edu/vestnik_irgtu/?ru/journals/2012/02

Ognyov D.V., Popova E.Y. (2014). Application forms forfaiting finance innovative projects. Studies of the Russian Academy of Entrepreneurship. 39 (196-204). 2073-6258. http://www.rusacad.ru/docs/nauka/Uch.Zap.39.pdf

Raizberg B.A., Lozovsky L.S, Starodubtseva E.B. (2004). Modern economic dictionary. Moscow. M: «INFRA-M».

Sheremet A.D., Ionova A.F. (2004). Finance management and analysis of enterprise. Moscow. M: «INFRA-M».

Soldatova A.O. (2013). Factoring and securitization of financial assets. Moscow. M: «Publishing House of the Higher School of Economics».

Weber, Manfred. (2007). Business computing. Moscow. M: «Omega-L». 